\title{
Collective action and individual choice: rethinking how we regulate narcotics and antibiotics
}

\author{
Jonny Anomaly
}

\section{Correspondence to \\ Dr Jonny Anomaly, Department of Philosophy, Politics, Economics (PPE), Duke University, 326 Perkins, Box 90204, Durham, NC 27708, USA; jonathan.anomaly@duke.edu}

Received 11 October 2012 Revised 29 November 2012 Accepted 7 January 2013 Published Online First 21 February 2013
To cite: Anomaly J. J Med Ethics 2013;39:752-756.

\begin{abstract}
Governments across the globe have squandered treasure and imprisoned millions of their own citizens by criminalising the use and sale of recreational drugs. But use of these drugs has remained relatively constant, and the primary victims are the users themselves. Meanwhile, antimicrobial drugs that once had the power to cure infections are losing their ability to do so, compromising the health of people around the world. The thesis of this essay is that policymakers should stop wasting resources trying to fight an unwinnable and morally dubious war against recreational drug users, and start shifting their attention to the serious threat posed by our collective misuse of antibiotics.
\end{abstract}

The availability of cheap antibiotics has saved countless lives, but it has also created a severe public health problem. Since the diffusion of antibiotic-resistant bacteria into our microbial environment is a predictable side effect of the widespread use of antibiotics, several authors have described the use of antibiotics as a collective action problem. ${ }^{1-4}$ Individual patients and physicians may benefit (or believe they benefit) in the short run by liberally prescribing and consuming antibiotics, but all of us would be better off if antibiotics were reserved for relatively serious infections. ${ }^{i}$

In contrast with antibiotics, the use of narcotics does not create a collective action problem since the relevant costs and benefits are borne by the users themselves. ${ }^{\text {ii }}$ Although many have argued that recreational drug use harms non-users, most of the harm associated with these drugs-such as theft and murder-is caused not by drug use, but rather

${ }^{\mathrm{i}}$ Physicians benefit from indiscriminate prescription by saving time on diagnosis, and by acceding to their patients' (often uninformed) request for antibiotics; patients benefit either because the antibiotics cure their infection, or because they work as a placebo and make patients feel as if something is being done, even if their infection is viral, or would have cleared up on its own anyway.

ii Although 'antimicrobial' is a more general term than 'antibiotic' (which designates only antibacterial agents), I will follow common usage and treat the terms as synonymous. For the sake of simplicity and style, I will treat 'recreational drugs' and 'narcotics' as synonyms, although technically 'narcotic' refers only to opiates and other pain-relieving drugs. By 'recreational drugs' I mean to include illegal narcotics such as heroin and marijuana, illegal stimulants such as cocaine, and legal drugs that people take to relieve pain, reduce anxiety, induce euphoria, etc. by the enforcement of laws that prohibit drug use. These laws create the conditions for black markets to flourish, for violence to be used as a preferred method of contract enforcement, and for police corruption to thrive. ${ }^{56}$

In what follows I explore some morally salient differences between antibiotics and narcotics, and conclude that government action is both more appropriate and more likely to be effective in regulating antibiotics than it is in criminalising narcotics. I then suggest how we can regulate antibiotics in a way that protects individual liberty and reduces aggregate harm. More specifically, I argue that we should implement a user fee on antibiotics which would generate revenue for research into new ways of diagnosing and treating bacterial infections.

\section{ANTIMICROBIAL DRUGS}

Access to antibiotics creates a collective action problem because the more we use them, the more evolutionary pressure we exert on bacteria to acquire and spread genes that confer resistance to antibiotics into our environment. It is widely understood that regions in which antibiotics are most frequently used (especially when they are used inappropriately) have the highest rates of antibiotic-resistant infections. $^{7}$

This suggests that preserving the efficacy of antibiotics is analogous to stewardship of the ocean and atmosphere: without the right combination of property rights or regulations in place, most people will tend to ignore the costs they impose on others because the costs are invisible and diffuse. I may know, for example, that flying to Fiji rather than Florida for my next vacation will produce more greenhouse gas emissions. But I also know that the pollution from my trip is not enough to significantly contribute to climate change. In the absence of price signals sent by a carbon tax, it is unlikely that many people will make meaningful sacrifices when the effects of their actions are relatively small, diffuse and invisible. The choice to use antibiotics is structurally similar to the choice to use pollution-emitting fossil fuels insofar as the benefits of use are borne by the individual, the costs are socialised, and the consequent harm is the product of many independent actions.

One difference between using antibiotics and pollution-emitting energy sources is that-whether she knows it or not-the individual herself can incur a significant portion of the costs associated with antibiotics. These costs can include increased virulence of non-susceptible microbes, colonisation by opportunistic pathogens such as Clostridium 
difficile, and the persistence of antibiotic-resistant bacteria in the user's body after completion of a course of antibiotics. ${ }^{8} 9$ Because genes that confer resistance are often cheap for bacteria to retain, resistant bacteria can survive in the body for many generations after antibiotic use has ceased. ${ }^{10} 11$ This is made possible by compensatory evolution, and by the conditional expression of resistance genes, which allows a bacterium to economise on energy until antibiotic use resumes. ${ }^{12}$ Since resistant bacteria can persist for so long, and since the genes that confer resistance are easily transferred between different bacterial species, ${ }^{13}$ people can bear at least two significant costs of using antibiotics: colonisation by opportunistic pathogens, and the creation of a personal reservoir of bacteria with antibiotic-resistant genes.

This is important because it suggests that non-coercive solutions to the problem of overuse may be more effective than they would be if all of the costs of using antibiotics were externalised. So far, however, efforts to inform physicians and patients about the harmful effects of careless consumption have had only a modest impact on behaviour. ${ }^{14}$ If physicians and patients fail to act on the available information, or if the information indicates that people do not incur enough personal costs from using antibiotics to cause them to change their behaviour, the basic collective action problem remains. Individually rational choices produce substantial social costs by creating reservoirs of antibiotic-resistant bacteria in human hosts and more generally in our shared microbial environment.

\section{RECREATIONAL DRUGS}

Does the use of recreational drugs harm others in similar ways? I have already mentioned that most of the violence and crime associated with narcotics is caused by laws that prohibit drug use, rather than drug use itself, and thoughtful supporters of drug prohibition agree. ${ }^{15}$ But some prohibitionists claim that drug users are more prone to violence, dependence and poor working habits, all of which harm other people. Other prohibitionists add that pregnant women who use certain drugs put their fetuses at risk, ${ }^{16}$ and that when adults have legal access to narcotics, minors, who lack the ability to make fully rational choices, will be able to access them more easily. ${ }^{15}$ They argue, in effect, that leaving people free to buy and sell recreational drugs creates large social costs.

These arguments should be taken seriously, but they do not present a convincing case for criminalising narcotics. First, consider the empirical evidence for the claim that drug users are more likely to commit acts of violence. Many experts agree that drugs do not directly cause users to become violent, except in the sense that some drugs in conjunction with certain environmental stimuli can reduce the inhibition of people already prone to violence. ${ }^{17}$ It is important to be specific here, since even the most ardent supporters of drug prohibition generally agree that opiates and marijuana may actually reduce pre-existing tendencies toward violence. ${ }^{16}$ It is often argued, however, that stimulants such as crack cocaine and methamphetamine increase the likelihood that people predisposed to violence will act on their predisposition.

The claim that stimulants tend to make people violent is often repeated but rarely supported with evidence. Experts on psychopharmacological violence-violence induced by intoxication-suggest that it is difficult to get good statistics on the connection between drugs and violence because there is a deep problem in disentangling causation from correlation, and because in many violent crimes it is not known whether the perpetrator was intoxicated. ${ }^{18}$ The little evidence we do have, however, suggests that alcohol (which is a depressant) is more likely to reduce inhibition and trigger violent predispositions than any illegal drugs, ${ }^{19}$ and most drug prohibitionists do not think this gives us good reason to make alcohol consumption a crime. Whatever reasons there might be to regulate alcohol-for example, to make drunk driving illegal-few think its connection with violence gives us sufficient reason to criminalise consumption. If this is true for alcohol, it should also be true for other recreational drugs that are currently illegal and have a much more tenuous connection with violence.

Consider next the emotional costs to friends and families imposed by some drug users. We should first distinguish casual users from addicts, since addicts constitute only a small percentage of users. ${ }^{5}$ Among opiate and amphetamine addicts, it seems clear that the longer they remain addicted to drugs, the more likely they are to neglect and alienate loved ones. But what follows from this? Should we criminalise behaviour that may lead people to disappoint their friends and family? There are many ways we can disappoint people we care about, including converting to Islam, working on Wall Street, or forgoing the family business in favour of a career in pornography. These choices may infuriate other people. But behaving in ways that make people angry or disappointed is hardly sufficient grounds for imprisonment. ${ }^{20}$ There are many ways our actions affect others, and not all of these actions are, from a moral standpoint, up for a democratic vote. If I choose to change professions or switch my religious, political or sexual identity, those who are disgusted by my choice may be 'harmed' in some sense. But this is not the kind of harm they have a right to be protected from, since this harm fails to undermine their basic interests. ${ }^{21}$ Similarly, some drug addicts may neglect their work or their friends and family. However, the emotional cost they impose on other people doesn't justify us in treating them as criminals, or forcing them to change their lifestyle.

A related argument adduced by prohibitionists is that drug addicts are less productive workers than they would be if they were sober, and that they harm others through their lack of productivity. ${ }^{16}$ It is hard to know what to make of this claim. It is true that opiates can make people less productive workers. But few people would argue that we have a moral obligation to be maximally productive workers, and that failure to do so warrants an extended prison term or any other form of legal punishment. There are many reasons people are unproductiveboredom, depression, bad nutrition and chronic pain all come to mind. To the extent that any of these are caused by bad habits, they are character vices. But, as with most character vices, social disapproval and friendly advice are more appropriate, and often more effective at changing people's behaviour, than criminal punishment. To the extent that diminished productivity is caused by addiction-to drugs, sex, food or anything else-there may be good reason to encourage addicts to enter rehabilitation centres. But this is a far cry from using state power to imprison or otherwise punish people who buy or sell recreational drugs.

Perhaps a more convincing case for criminalising the use and sale of recreational drugs is that, in the absence of harsh penalties, supply would increase, making it easier for adolescents to access harmful drugs. ${ }^{15}$ Similarly, some say that increased supply would make it more likely that pregnant mothers would use drugs that cause harm to their fetus, and this justifies criminalising markets for recreational drugs. ${ }^{16}$ These arguments are similar in the sense that the concern is to protect non-adults who lack the capacity to voluntarily incur the risks of drug use. 
But both arguments are specious. First, the evidence we have from the only country that has decriminalised all recreational drugs, Portugal, suggests that consumption has not significantly increased for most drugs, and has actually declined for some drugs. $^{22}$ The evidence from Portugal shows that greater accessibility does not necessarily lead to more drug use by either adults or children. Second, if we are especially concerned to protect fetuses from their mother's drug use, it is inefficient to target all drug users. Instead, we should try to make sure women understand the risks associated with ingesting certain chemicals -including alcohol, mercury, lead and cocaine-during pregnancy. Finally, it is unfair to treat all drug users alike when only a small fraction of them harm others in morally relevant ways. Imprisoning middle-aged men in order to prevent pregnant women from causing drug-induced harm to their fetus is on a par with imprisoning postmenopausal women for eating mercury-rich seafood, which has the power to impair fetal development in pregnant women. It is perfectly legitimate to impose criminal penalties on people who distribute dangerous drugs to children or knowingly harm a developing fetus. But this does not justify using the power of the state to punish all drug users.

Recreational drug users, then, fail to harm others in ways that justify the use of government coercion to prevent them from using drugs. ${ }^{\text {iii }}$ When an adult decides to ingest a drug in order relieve pain, reduce anxiety, or just have fun, the user bears most of the morally relevant costs and benefits of his consumption. When the same person takes a course of antimicrobial drugs-especially when taking it to relieve symptoms that it lacks the power to cure-other people with whom the consumer shares a microbial environment may incur a great deal of the cost of his consumption. Specifically, transmissible infections resistant to antibiotics often kill people, or at least impair their health and make their infection much more expensive to treat. This feature gives antimicrobial drugs a fundamentally different moral status from recreational drugs, and it suggests that current policy priorities are based on moral confusion, scientific ignorance, or both.

\section{CHANGING COURSE}

The choice to use antibiotics can affect others in positive and negative ways. If one person uses an appropriate course of antibiotics, he may recover from an infection and prevent himself from becoming a vector. But he also increases the risk of harm to himself and others by increasing the prevalence of antibiotic-resistant bacteria in his own body and in the general environment. Thus, Margaret Battin and her colleagues conclude that the choice to consume antibiotics 'is partly a problem of prudence, of considering apparent short-term benefits against unknown but serious risks for oneself now and oneself in the future; and it is also a collective action problem, because the resistance one engenders in one's own body may also affect others'. ${ }^{23}$

In economic terms, the collective action problem stems from the fact that the price of antibiotics fails to include the social cost of resistance. This price distortion is exacerbated by healthcare systems in which third-party payers-including governments and health insurance companies-blind physicians and patients to the full cost of treatment. When economists see price

\footnotetext{
${ }^{\text {iii We might, however, justify publicly funded treatment centres, which }}$ seem more effective (and more compassionate) than turning drug users into enemies of the state.
}

distortions created by externalities, their first reaction is to find a way to force consumers to 'internalise externalities'-that is, to increase the extent to which people bear the costs and benefits of their own actions. Several ways of achieving this goal have been proposed, ranging from consumption taxes and financial incentives to reward firms for conservation, to marketable permits and patent adjustments for antibiotics. ${ }^{24} 25$ But because bacterial evolution is unpredictable, and resistant bacteria are invisible to the people who host them, the goal of fully internalising externalities may be impossible to achieve, and ethically undesirable.

What, then, should be done to minimise the collective harm associated with antibiotic use? Scholars have reviewed a range of policies that could work in conjunction to reduce the problem of resistance. Educating patients and clinicians about the nature and risks of antibiotics can go some way to reducing careless consumption. ${ }^{26}$ We should also phase out the subtherapeutic use of antibiotics in farm animals, ${ }^{27}$ and forbid factory farming more generally. ${ }^{\text {iv }}$ This would help preserve the efficacy of existing antibiotics for human use and reduce the threat of zoonotic viral infections such as avian flu and swine flu. ${ }^{28}$ For antibiotics to remain effective, we may also need to incentivise pharmaceutical firms to conserve existing drugs ${ }^{29}$ and encourage developing nations to ban over-the-counter sales of antibiotics. Finally, wealthier nations should be prepared to share information and surveillance technology with developing nations in order to monitor outbreaks of resistant pathogens. This would benefit people in all nations, and could help build trust between leaders of nations that might eventually forge more ambitious agreements to solve global problems ranging from antibiotic resistance to climate change.

Another proposal would be for governments to impose a Pigovian tax on each course of antibiotics that reflects the social cost of use. ${ }^{30}$ Pigovian taxes attempt to reduce socially harmful activities by raising the cost of those activities. In theory, Pigovian taxes would diminish socially harmful consumption (depending on the size of the tax, and on who pays it), and provide a source of revenue that could fund basic science research and provide compensation to victims of antibiotic resistance. However, if the precise social costs (and benefits) of consuming antibiotics cannot be calculated, and if those who create and enforce public policy are imperfect agents for the people who put them in power, we shouldn't support a policy that presupposes perfectly informed and benevolent government agents. Accordingly, Battin et al suggest that, instead of a complex system of antibiotics taxes, we should simply 'add a fixed amount, say a \$1 surcharge to every course of a first generation antimicrobial, and a slightly larger surcharge-say, \$2-to every course of a second generation antimicrobial. Funds generated in this way could be used to support antimicrobial research either by the government directly or through grants and contracts'. ${ }^{23}$ Since the surcharge proposal hasn't been fully developed, I want to consider in a little more detail why it's a good partial solution to the problem of antibiotic resistance.

First, a modest surcharge (or 'user fee') has some of the virtues of a Pigovian tax without its vices. Like a Pigovian tax, a surcharge can be flexible, but, unlike a Pigovian tax, it is a flat fee and does not require us to perform the impossible task of

${ }^{\mathrm{iv}}$ In addition to banning the sub-therapeutic use of antibiotics in livestock, we might tax therapeutic antibiotics, which would drive up the cost of factory farming, but still allow farmers to treat animals who get sick through no fault of the farmer. 
calculating the precise social costs (or benefits) associated with the aggregate use of a particular antibiotic drug at a particular time. A surcharge reflects the fact that there are likely to be social costs from widespread use, that the costs vary between different drugs and different people, and that users of these drugs should pay some kind of compensation to other people for their use of an exhaustible resource. Unlike a Pigovian tax, however, a surcharge would not raise the cost of antibiotics so much that poor people who need them will be priced out of the market. This is an advantage from the point of view of fair access, but it may also be better for wealthier people since everyone is better off when those who need antibiotics for a transmissible infection can afford to finish a complete course. Thus, antibiotics user fees strike a balance between the competing values of efficiency and fairness: they don't require precise calculations, and they keep the access fee low enough that poor people will not be deterred from consumption that is both individually and socially beneficial.

A second reason for supporting a user fee (a reason that could also be used to support Pigovian taxes) is that it is consistent with an identity-independent conception of harm. ${ }^{31}$ According to the identity-independent view, we can harm people who do not yet exist, or contribute to a chain of events that predictably harms people even if it's unpredictable which particular people will be harmed, or how responsible we are for causing harm. Since a single person's use of antibiotics merely raises the probability that he will become a vector for the transmission of antibiotic-resistant bacteria, we shouldn't think of the harms associated with antibiotic use in the same way we typically think of harmful actions. If a bully bludgeons you with a sledgehammer and watches you bleed to death in a dark alley, he should be punished because he bears full responsibility for your death. But many modern social challenges-including threats to public health and our environment-require a fundamentally different way of thinking. My use of antibiotics may lead to an increased risk of infection by another person by subtly influencing the composition of our microbial environment. But in most cases there will be no direct causal link between my use of antibiotics and another person's compromised health. Even when such links exist, they are generally impossible to discover. Thus, rather than punishing people for any particular harms associated with the use of antibiotics, we should work with an identity-independent conception of harm, and favour policies that increase the extent to which individually advantageous actions also produce socially beneficial rather than harmful outcomes. A user fee can do this by raising the marginal cost of emitting genetic pollution through the use of antibiotics, and by using revenues to fund research related to antibiotic resistance, and conservation of existing antibiotics. A Pigovian tax would accomplish the same end, but would suffer from the drawbacks mentioned above.

A third reason for supporting a user fee for antibiotics stems from the fact that some of the basic science research that produces fundamental breakthroughs in our understanding and treatment of infectious disease is not profitable for pharmaceutical firms to perform. This may seem counterintuitive. If the global rate of antibiotic resistance is accelerating, and if treatment of infectious disease creates new profit opportunities, we

\footnotetext{
${ }^{v}$ Although supporters of a Pigovian tax cannot overcome the severe information constraints faced by policymakers, they might solve the problem of underconsumption by the poor by using some of the revenue from a Pigovian tax to subsidise drugs for the poor.
}

should expect profit-seeking firms to develop new drugs to treat emerging infections. However, there has been a welldocumented decline in the development of new antibiotic drugs over the past few decades. ${ }^{32}$

One explanation for this is that most early antibiotics were extracted from organisms that produce endogenous antibacterial agents. This made them easy to discover and cheap to produce. As resistance to these chemicals has become more widespread in the bacteria that colonise us, many new antibiotics have to be synthetically created in laboratories, and this process is so lengthy and costly that some firms have abandoned their efforts altogether. Another explanation for decreased investment by pharmaceutical firms is that newer classes of antibiotics, and novel ways of treating microbial infections, require basic science research, which is not patentable, and therefore not profitable, at least in the short term. ${ }^{\mathrm{vi}}$ To the extent that information gleaned from basic science research cannot be patented, or is not immediately profitable enough for firms to justify large investments, it is a public good in the technical sense that its potential benefits are both non-excludable and non-rival. ${ }^{33}$ Although some public goods can be supplied privately, as the number of potential beneficiaries and the cost of producing the goods increase, private provision becomes less likely and government funding may be the only effective way to supply it. An antibiotics user fee is a minimally intrusive way of increasing public funding for basic science research which can be used by private firms to develop new treatments for infections.

A user fee would not be a panacea. But it could be a crucial part of a multidimensional approach to the problem of resistance. User fees are especially attractive because of their fairness and simplicity. Their capacity to deter socially harmful consumption will be limited by the size of the fee, but the revenue generated by even a modest fee may foster fundamental breakthroughs in resistance-related research, which-from a moral standpoint-can be thought of as indirect compensation to future victims of antibiotic-resistant infections.

\section{CONCLUSION}

I have assumed the liberal view that individual adults should be free to make their own choices, even choices others consider repugnant, provided they bear most of the morally relevant costs. If, as I have argued, the choice to use recreational drugs fails to harm others in morally significant ways, we should call off the 'war on drugs' and consider more humane and less intrusive alternatives for helping drug addicts. By contrast, the use of antibiotics creates a global, inter-generational collective action problem in which the consumption choices of each person have significant welfare effects on others. This suggests that there is a much stronger justification for governments to regulate the use of antimicrobial drugs than there is for regulating recreational drugs. Yet in many countries around the world, antibiotics are either sold over-the-counter or casually dispensed without much consideration of the social consequences. Instead of a fully free market for antibiotics, I have argued that we should think hard about how to regulate them in a way that carefully balances individual liberty and public health.

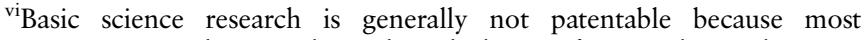
governments and courts have denied claims of ownership rights over fundamental insights about how the world works. For example, laws of nature or mathematical theorems that describe the relationships between quantum particles or the mechanisms of bacterial evolution are generally left in the public domain so that individual firms and people cannot withhold their discovery from others.
} 
Acknowledgements The author would like to thank Jeffrey Miron, Michael Huemer and Iskra Fileva for comments and encouragement.

\section{Competing interests None.}

Provenance and peer review Not commissioned; externally peer reviewed.

\section{REFERENCES}

1 Kades EA. Preserving a precious resource: rationalizing the use of antibiotics. Northwest Univ Law Rev 2005;99:611-75.

2 Laxminarayan R. Economic issues related to antimicrobial resistance. In: Roberts JA, ed. Economics of infectious disease. Oxford, UK: Oxford University Press, 2006:49-64.

3 Selgelid MJ. Ethics and drug resistance. Bioethics 2007;19:227-89.

4 Anomaly J. Combating resistance: the case for a global antibiotics treaty. Public Health Ethics 2010;3:13-22.

5 Miron JA. Drug war crimes: the consequences of prohibition. Oakland, CA: The Independent Institute, 2004.

6 Benavie A. Drugs: America's holy war. New York: Routledge Publishing, 2008.

7 Nugent $R$, Back E, Beith A. The race against drug resistance. The Center for Global Development, 2010. http://www.cgdev.org/section/initiatives/_active/ drugresistanceglobalhealth (accessed Jan 2012).

8 Dancer SJ. How antibiotics can make us sick. Lancet Infect Dis 2004;4:611-19.

9 Cars 0 , Högberg LD, Murray M, et al. Meeting the challenge of antibiotic resistance. BMJ 2008;337:726-8.

10 Salyers AA, Amabile-Cuevas CF. Why are antibiotic resistance genes so resistant to elimination? Antimicrob Agents Chemother 1997;41:2321-5.

11 Lenski RE. Bacterial evolution and the cost of antibiotic resistance. Int Microbiol 1998;1:265-70.

12 Andersson DI, Levin BR. The biological cost of antibiotic resistance. Curr Opin Microbiol 1999;2:489-93.

13 Levy SB, Marshall B. Antibacterial resistance worldwide: causes, challenges and responses. Nat Med 2004;10:122-9.

14 MacDougall C, Polk RE. Antimicrobial stewardship programs in health care systems. Clin Microbiol Rev 2005;18:638-56.

15 de Marneffe P. Against legalization. In: de Marneffe P, Husak D. The legalization of drugs: for and against. UK: Cambridge University Press, 2005;109-98.
16 Wilson JQ. Against the legalization of drugs. Commentary 1990;89:21-8.

17 Boles SM, Miotto K. Substance abuse and violence: a review of the literature. Aggress Violent Behav 2003;8:155-74.

18 Goldstein P. The drugs/violence nexus. J Soc Issues 1985;15:493-506.

19 Parker R, Auerhahn K. Alcohol, drugs and violence. Annu Rev Sociol 1998;24:291-311.

20 Huemer M. America's unjust drug war. In: Rachels J, Rachels S. The right thing to do. 4th edn. New York: McGraw Hill, 2007:133-43.

21 Feinberg J. Harm to others: the moral limits of the criminal law. Oxford, UK: Oxford University Press, 1987.

22 Greenwald G. Drug decriminalization in Portugal. Cato Institute White Paper 2009. http://www.cato.org/pub_display.php?pub_id=10080 (accessed Jan 2012).

23 Battin MP, Francis LP, Jacobson JA, et al. The patient as victim and vector: ethics and infectious disease. Oxford University Press, 2009.

24 Smith RD, Coast J. Controlling antimicrobial resistance: a proposed transferable permit market System. Health Policy 1997;43:219-33.

25 Outterson K, Samora J, Keller-Kuda K. Will longer antimicrobial patents improve global health? Lancet 2007;7:559-66.

26 Wilton P, Smith R, Coast J, et al. Strategies to contain the emergence of antimicrobial resistance: a systematic review of effectiveness and cost-effectiveness. BMC Health Serv Res 2002;7:111-17.

27 Gorbach SL. Antimicrobial use in animal feed-time to stop. N Engl J Med 2001;345:169-78.

28 Greger M. The human/animal interface: emergence and resurgence of zoonotic infectious diseases. Crit Rev Microbiol 2007;33:243-99.

29 Kesselheim AS, Outterson K. Improving antibiotic markets for long term sustainability. Yale J Health Policy Law Ethics 2011;11:101-68.

30 Rudholm N. Economic implications of antibiotic resistance in a global economy. $J$ Health Econ 2002;21:1071-83.

31 Fishkin J. Justice across the generations. In: Fishkin J, Laslett $P$, eds. The limits of intergenerational justice. New Haven, CT: Yale University Press, 1992.

32 Spellberg B. Rising plague: the global threat from deadly bacteria and our dwindling arsenal to fight them. New York: Prometheus Books, 2010.

33 Stiglitz JE. Knowledge as a global public good. In: Kaul I, Grunberg I, Stern M, eds. Global Public Goods. Oxford, UK: Oxford University Press, 1999;308-25. 


\section{Collective action and individual choice: rethinking how we regulate narcotics and antibiotics}

Jonny Anomaly

J Med Ethics 2013 39: 752-756 originally published online February 20, 2013

doi: 10.1136/medethics-2012-101160

Updated information and services can be found at:

http://jme.bmj.com/content/39/12/752.full.html

\section{These include:}

References This article cites 21 articles, 3 of which can be accessed free at: http://jme.bmj.com/content/39/12/752.full.html\#ref-list-1

Email alerting Receive free email alerts when new articles cite this article. Sign up in service the box at the top right corner of the online article.

$\begin{array}{cc}\text { Topic } & \text { Articles on similar topics can be found in the following collections } \\ \text { Collections } & \text { Press releases (17 articles) }\end{array}$

Notes

To request permissions go to:

http://group.bmj.com/group/rights-licensing/permissions

To order reprints go to:

http://journals.bmj.com/cgi/reprintform

To subscribe to BMJ go to:

http://group.bmj.com/subscribe/ 